\title{
Francesco Venezia: Time, Memory, Senses as Elements of Architecture
}

\author{
By Raffaella Maddaluno*
}

\begin{abstract}
The design approach of Francesco Venezia (1944), master of Italian architecture appears unpopular, out of step with an architectural world that increasingly faces every gesture of building and design practice as a desire to demonstrate the "exceptional". The distance that Venezia keeps from perfection that does not signify methodological approximation or programmatic superficiality but a respect for everyday human life, distances his works from the danger looming over contemporary architecture: considering every opportunity in architecture as a self-portrait, as an object constantly longing for the fixedness of fame, an aspiration for the eternal. The humanity of architecture, everyday life and not the desire for eternity leads to the silence of forms and the wisdom of building, placing the work of the architect on a respectful path already mapped out where, before engaging or becoming carried away by temporal syntax, it is right to relinquish a hedonistic desire for power. This deep respect for the learning of a language that renounces exemplarity and novelty is also found in the teaching of Francesco Venezia and in the themes proposed as objects of design reflection for students. This paper aims to describe some of architectural experiences in which Francesco Venezia leads to concepts like time, memory, humanity, integrity and etic of architecture. ${ }^{l}$
\end{abstract}

\section{Introduction}

The research and constructive experience of Francesco Venezia demonstrates that history must be considered as a heritage of living examples. The direct knowledge of these examples cancels out the lapse of time, which sometimes impedes the work. This does not imply a lack of respect for its specificity and uniqueness, instead having the ability to go beyond the ineffective sacralisation of the existing.

In his design and teaching experience the ability to relate to themes like "time" is evident. His buildings seem to offer the possibility of time, they seem to predict the effects of time and they also seem to slow down the use of our time.

\footnotetext{
*Assistant Professor, Lisbon School of Architecture, CIAUD, University of Lisbon, Portugal.

1. Francesco Venezia is an architect from Naples. He was born in Lauro in 1944 . He combined, during his career, the activity of university professor (professor of architectural composition at the University Institute of Architecture of Venice) with a long-lasting and accurate professional activity. His career was enriched by numerous experiences of foreign academic sharing: lecturer at the Berlin Sommerakademie (1987), visiting professor at the Graduate School of Design of Harvard University (1988), Professeur invité at the École Polytecnique Féderale di Lausanne (1989), lecturer at the University of Italian Switzerland in Mendrisio (2010). His works won numerous awards, including the "Architecture in Stone International Awards" in Verona at the Faculty of Law and Economics and the university library in Amiens in 1997. He is also an academic at the Accademy of San Luca.
} 
Another specificity of his work is the sensory link he has with architecture, due to this we can perceive ancient presences, vanished myths and the unheard voices of chosen places.

His lesson consists of teaching the form of architecture as a cultural phenomenon, strongly linked to life and to man. His culture, real, varied, built and put to the test with time, makes his opportune interventions inter-temporal and classic. It is mainly these themes that the following text deals with.

\section{Project and Fragment}

If we stopped to scroll through the sketches of Venezia's project, we would have before us a geography of fragments. Each fragment has its own completeness, it is part of an object to which something has been removed, or something added, or inside it has been excavated. It is a tracing of foundations, pedestals and excavations. It is a constant reflection that oscillates between sediment and ruin, but which, as a final result, returns an intact architecture. These parts of which it is composed, are separated from a temporal point of view, but perfectly adherent to the nature of the real and daily world, made of fragments.

His sketches, as well as his writings are clearly composed. They are attentive and respectful of limits and brevity. They are parsimony exercises but correct expressions of creative clarity. They are not manifestations of artistic desire, however instead are rigorous tools to find the right rule, the correct spatial modulation, the balance between the whole and its parts (See Figure 1).

Continuing on with the relationship between project and fragment it would be impossible to not mention the Gibellina Museum or Palazzo di Lorenzo (1984) one of the interventions Venezia completed after the earthquake. It is a building that fits into a reconstruction plan of the old Gibellina, which after a disastrous earthquake (1968), was cancelled. The new Gibellina is a carousel of architectural exuberance and of artistic license.

It is actually a building that does not have a real function. Its function coincides with its presence, like ruins or wrecks. The Venezia Museum appears silently in the midst of this whirlwind of design self-references. The ruins appear in the Roman countryside, or the ancient vestiges in the bare landscapes of the Greek lands.

As Dal Co says, referring to the study for San Leucio, and for the project for the temple of Fortuna Primigenia in Palestrina (1984): "the question for which he seeks answers comes from the realization of the precariousness that architecture is capable of opposing the irruptions of time and needs in their most diverse manifestations. It is not for nothing that Venezia is attracted to the insistence of the ruins, and the ruins repeatedly try to make use of design material in the proper sense, after having taken them as a touchstone" (see Figure 2). 

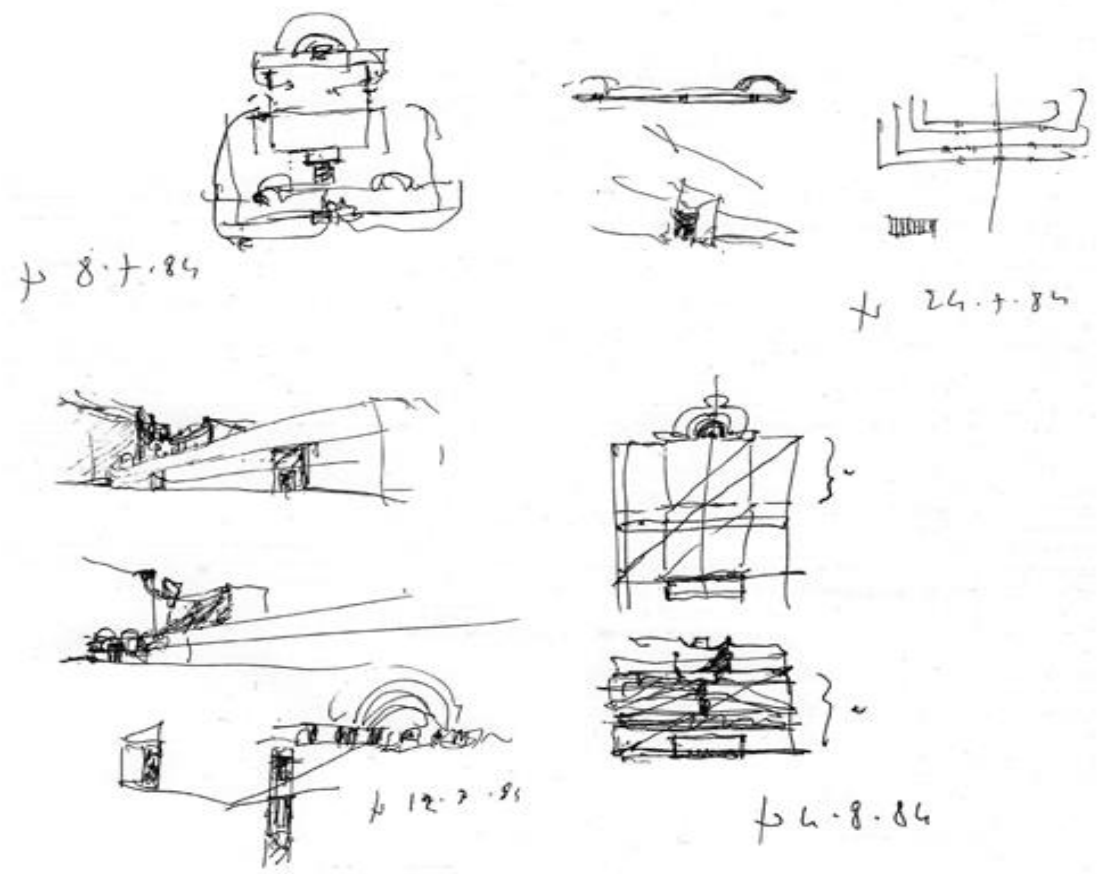

$$
\text { t. } 4 \cdot 8 \cdot 84
$$

Figure 1. F. Venezia. Study Sketches of the Temple of Fortuna Primigenia in Palestrina

Source: http://www.engramma.it/eOS/index.php?id_articolo=823.

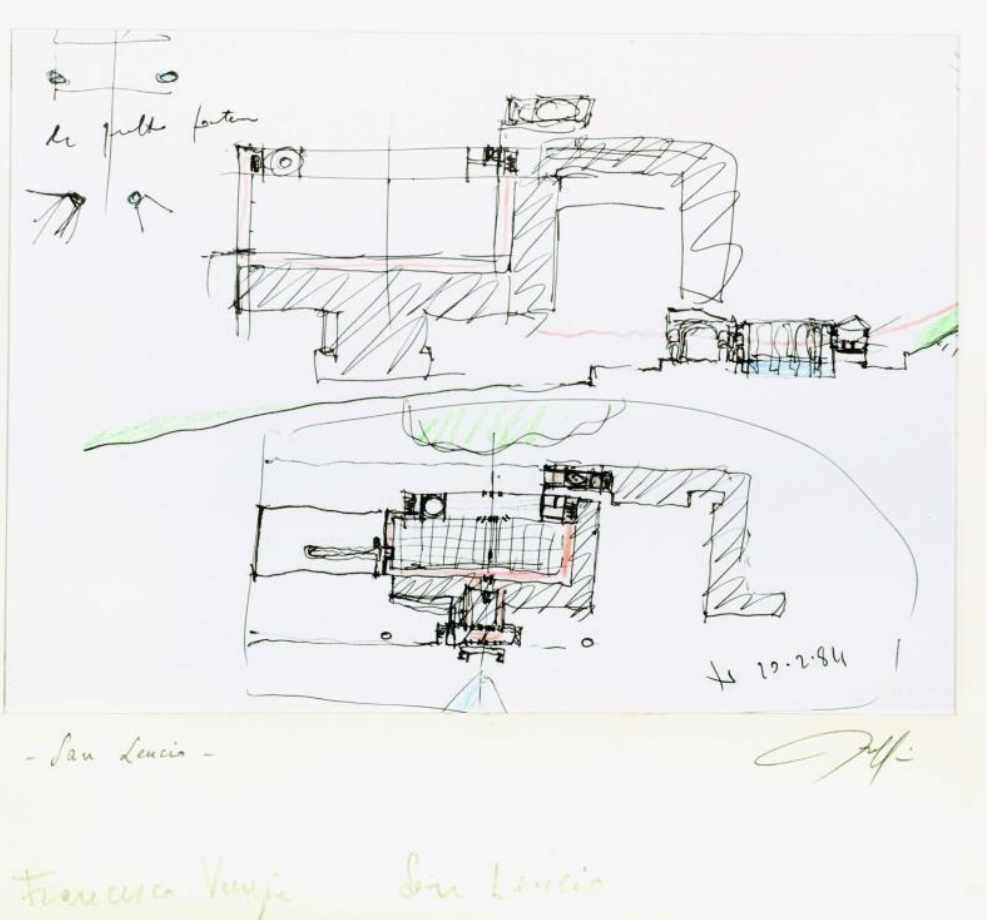

Figure 2. F. VENEZIA, "Il Regno Dellacqua", a Project Developed in the Context of the International "San Leucio: Five Proposals for a Territory", 1984 Contemporary Archive | Architectural Drawings | Online Collections Source: https://www.pinterest.it/pin/393220611197548889/. 
From these reflections it can be deduced that the works of Francesco Venezia transform the many manifestations of architectural practice into one unit, but they also come to terms with the experience of the typical and necessary fragmentation of the human condition. This dual collocation seems to better relate to the dual character with which we perceive the world in cases such as multiplicity and unity, continuity and discontinuity, convergence and fragmentation.

The unfinished architecture, very often the subject of his own work, is an expression of this duality, of the human weakness and of the mortality of his work. The incompleteness, desired or provoked by decadence, as in the case of ruin, returns architecture to a dimension in which the ephemeral things have no place and then time turns to matter.

As we can read from the pages of his text dedicated to the ruins and the unfinished both the ruins and the unfinished buildings possess a strong aesthetic value, because in their FRAGMENTATION, in their incompleteness it is contained a force that moves us and this force places us constantly in relation to a feeling of imperfection, but also to a different beauty. It is the beauty that appears suddenly, like when a roof falls and disclose a space leaving the roof open to an unexpected sky: "It is like a broken shell: destroyed inside making us discover a fascinating world." ${ }^{2}$

The ruin always covered a fundamental role in the perception of mankind's space; it has always offered the possibility to make an experience of reality that possesses a poetic nature because it allows those who see it to lose themselves indefinitely over time. A journey that is human but that can incite to explore the boundaries of the infinite, because it has no limits. And the possibility of approaching infinity has always moved mankind, deceiving him that he can dominate time, but that actually only drives him to become aware that he is an infinite human, that perhaps, as Venezia says, it would be more correct to be called "indefinite".

There is a second opportunity, for a building, to enter into a relationship with the "break", and it happens when buildings are not finished, so that they are delivered to oblivion even before being finished. They are buildings complementary to the ruins, because they are what is ultimately a project but not the realization of the project itself. In both cases we are dealing with something fragmentary and mutilated.

"If we look around, reality is full of unfinished buildings, buildings that had a constructive story in which, because of the excessive ambition of the project - a building too big - or for unforeseen events - a war, an invasion, a political change or because the money simply out, the building materials had finished or there was a break in the construction process. These are complementary buildings of the ruins; they are the surviving part of a completed project." 3

This introduction serves to frame the theme of the design exercise that Francesco Venezia assigned, in one of his teaching years, to his students during the course of the first year of Design Laboratory in Venice. We also need to demonstrate that there is no boundary of interest between his theoretical

\footnotetext{
2. F. Venezia, Rovine e non Finito (Venezia, 2007), 13.

3. Ibid, 14.
} 
reflections, his built works and his research aimed at teaching. His themes constantly focus on concepts such as time, interpretation of memory, relationship with the presence, whether it is a place or a building.

The students were assigned a completed project of four great masters of the Modern-style, and they were asked to "simulate through models and drawings the realization of one of his fragments, taking care of finding a certain compensation for its interminativeness." ${ }^{4}$ The chosen buildings were: The Unite d'habitation of Strasbourg by Le Corbusier; the Bergaliden Crematorium of Sigurd Lewerentz; the Church for the new hospital in Venice by Le Corbusier and Guillermo Jullian de la Fuente; the Christian Catholic Church of Zion City by Frank Lloyd Wright. The results were surprising.

For example, in the case of the Crematorium of Lewerentz, a project commissioned by the Helsinborg Society in 1914, the building envisaged an elongated and narrow block that at the back should have stretched over a small lake, like a bridge. From this lake a ramp would have had to connect to the first room of the crematorium, a high, domed space, where the funeral ceremonies would have had to be performed. The unfinished theme, in this case, under the supervision of Francesco Venezia and his collaborators (in this case the architect Stanislao Fierro) was interpreted by his students in two ways. In the first hypothesis, not modifying the intended use of the building, the students hypothesized that the vaulted room had never been built; in the second it could have been built up to the last courses of the wall that would have to had kept the roof. Therefore, in the second solution, the roof would not have really been built. Seemingly the theme of the course, is difficult to execute for inexperienced first year students due to a lack of special awareness but Venezia in his presentation of the exercise says: "I avoid elementary exercises, preferring complex exercises supported by an idea that you will develop with the resources of your experience, which is necessarily limited. (...) it is natural that you have little technical and instrumental skills, little experience. But there is no experience, there are no technical skills and tools able to flourish and bear fruit in the absence of an ideal motive."

The praise of ruin and of the unfinished in architecture may seem a position vaguely linked to the past, but this is due to a superficial interpretation. The themes he deals with are deliberately old-fashioned, but very actual if not urgent. His architecture is a constant warning against the anxiety of perfection of contemporary architecture.

This warning should not be confused with a lack of semantic precision or absence of grammatical and programmatic discipline; on the other hand, Venezia brings his work towards a temporal dimension that goes beyond the limits of the antique period and reaches the primordial one. It is not a coincidence that the story that seems to describe in a better way the dangers of perfection in architecture, as a direct consequence of a lack of humility and of the non-assumption of the concept that perfection is possible only when we entrust everything to the divine, is represented by Mircea's essay Eliade that tells the timeless legend of Manole. A

4. Ibid, 15 . 
figure representing a master who entrusts the rite of building to the ritual of sacrifice, trying to solve the continuous cases of deaths of his workers on his building site. He understands that it is the sacrifice of the body of his young bride, who can defeat the danger of the failed construction, due to the recurrence of the accidental event.

Francesco Venezia relates to the interruption of the life-time of architecture with an act of suspension. It suspends time by giving up, which does not mean getting away from it: it rather means refusing to entrust the architectural occasion that it has as concerns the temptation to create a "first work". An approach that seems unpopular, far from the tendency of architecture that is more and more related to every practical action about building and that considers the construction as a will to show the exceptional.

\section{"Universal for Renunciation"}

He chooses Paestum as the setting of the montage because, as he says, those temples have an archaic Doric structure, not yet perfected, "and perfection is already a sign of decadence". In Paestum, in particular in the basilica, the Doric shows his will to be. It is in the state of maximum power. It nourishes us." ${ }^{5}$

According to Venezia, the Mies building achieves the right latitude, after having escaped from Berlin, and appears with its dark steel, its peristyle and its glass cell. A cell "from which the Gods walked away and into which men have entered." ${ }^{6}$ What motivated the choice of these three buildings and this unusual approach? What do they have in common?

They refused the superfluous, and by renouncing the superfluous they became universal. The two temples have renounced that because they have lost the superfluous in the time that degrades, shapes, uniforms; the temple of Mies has renounced it because it is made of steel "and renouncing the superfluous, the ephemeral signs of actuality, of fashionable things, thanks to the use of innovative materials -steel, crystal-is paradoxically universal. Universal for renunciation." ${ }^{7}$

By losing the superfluous they belong to the world of MEMORY, which preserves the essential, and ensures that spaces are inhabited by ghosts.

In the choice of Greek temples and references to the classical architecture made by Venezia, it seems to be the willingness to relate the dimension of BECOMING, which is the human measure, with the dimension of the ABSOLUTE, which is the divine measure. The absolute has no movement, is in a balance without gaps; the gap with respect to a horizon produces movement and the passage of time, referring to a time in evolution. ${ }^{8}$

5. Venezia, Che Cosa è l'Architettura. Lezioni, Conferenze, un Intervento (Milano: Electa, 2013), 101.

6. Ibid.

7. Ibid.

8. A. Colonna, Genealogia del Presente e Storiografia dell'Architettura. Appunti dalla Didattica e per la Ricerca (Potenza: Calebasse ricerche, 2015), 78. 


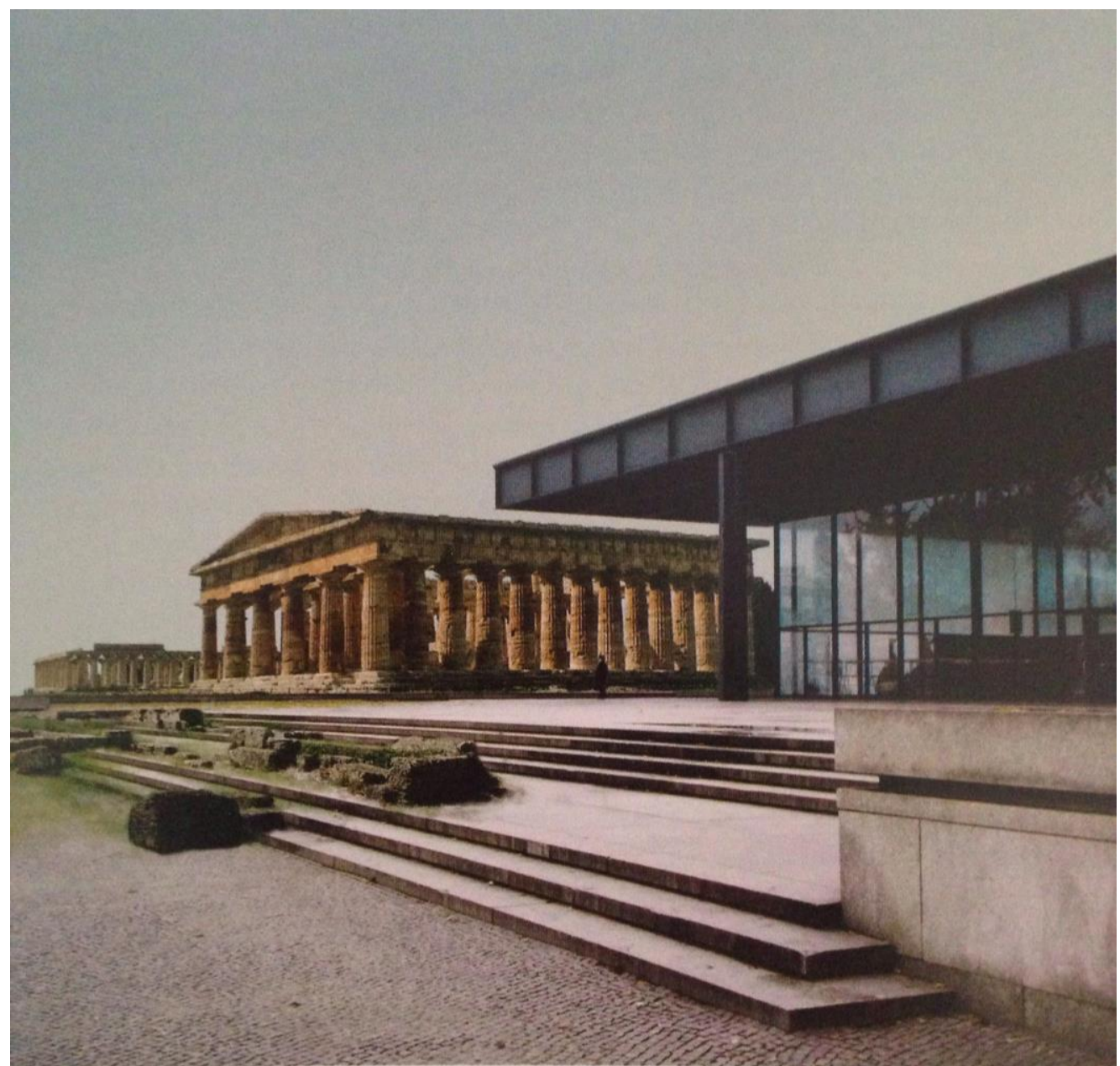

Figure 3. Photomantage "La piana dei Templi" where the Nationalgalerie of Mies Van der Rohe, the Ruin of Nettuno's Temple, and the Basilica of Pestum can be seen

Source: Venezia, Che Cosa è l'Architettura. Lezioni, Conferenze, un Intervento (Milano: Electa, 2013), 99.

This photomontage reminds us of a respect and an obligation to refer to matter and time by Venezia and to their mutual relationship. It seems that architecture for him is a gesture of trust deposited in matter, in the hope that this will last and remain faithful to the functions assigned to it: "The lifetime is the label that quantifies the time assigned to an object (...) The lifetime therefore measures the perseverance of entities in their identity." 9

This perseverance in opposing resistance to the uncertainty that time brings is present in its architecture. Its buildings seem to be the sum of a series of transformations underwent by the material they are made in order to adapt to the place. It is a way of doing classical architecture, recognizing that there are two ways of naming and conceiving time: Aion and Kronos.

Kronos is the time that enters the matter in a corporeal form, Aion is the time that has been freed from matter, and so it becomes immortal. Kronos acts in the

9. F. Espuelas, Madre Materia (Milano: Marinotti, 2012), 103. 
present, he thinks that there is neither the past nor the future, so they are conceived as a form of the present. When time is not only the time of the present but also memory, then we are in the field of Aion. "Time-duration and time-becoming possess the two different faces of making architecture. Aion's time is that of the project and the prefiguration of the building, but also of that sort of retroactive project that is historiography and criticism. A time that anticipates and reconstructs, which ventures into the future (Project) as in the past (History) and which is endowed with the plasticity of the projective imagination." 10

Aion deals with the relationship between the beginning and the end, Kronos takes care of the time that is perceived through the body. With the architecture of Venezia, the body (time-matter) and the mind (time-project) are in harmony but what really appears in his experiences is the third form of time, what the Greeks called "the time of opportunities ", Kairos. "The Greeks have a name to indicate the coincidence between human action and time. It is called Kairos the moment when time is favorable and human actions are good: occasion and time are favorable." 11

This idea of time is related to human action, to the ethics of his behavior. The buildings of Venezia appear "opportune", they are conceived and constructed in a breach opened in the temporal sequence of the narration of a place. This breach, which is not always painless, is the signal that it is necessary to enter into the dialogue based on resistance and acceptance with the ground.

To better understand this concept, we can refer to an interview left by Venezia, where he talks about the design process of Gibellina. At a certain point he clearly explains that projects that have a positive outcome are those whose assignment comes when an idea has already matured in the author's mind. This maturation does not depend on the nature of the assignment, nor on the site. It is the idea that acts as a link with the specific situation. But the idea, in order to be valid, must take over an "opportune time", that is the final moment of a maturation process. "It could be said that more than a good relationship with the context, one must have a good relationship with their own mind and one should arrive at assignment prepared with an idea. When the task is given, the strength of the idea becomes an "interlocutor" of the specific situation. The stronger the idea, the stronger the relationship between one's idea and the needs of the site in which to insert the project. "

To appreciate the buildings of Venezia, you need to take your time. Laziness is not permitted to those who look at them. In a world where "everything is immediate" is the rule, in contrast, they require slowness of understanding. As Dal CO says: "they offer the gift of their own time, of an interval - they offer as a gift to the public distracted by modernity, the possibility of losing, due to the architecture and a bit of time"

10. Ibid, 106.

11. P. Aubenque, Le Prudence chez Aristote (Paris: Presses Universitaires de France, 1963), no. 8, 107. 


\section{Architecture and the Sensorial Design}

"Man employed centuries to make perfect the grammar of architecture, and, as I often repeated to my students, who are able to dominate and to know the syntax and grammar of a stone building, can also dominate the syntax and the grammar of a steel and crystal building"12

A conscious design presupposes the control of the sensorial effect that the building will cause on the body of those who will inhabit it, who will look at it and who will cover its space. The body, through the senses, measures our relationship with space. Space organizes our life experience on earth, relating to time in its duration.

Several experiences concerning the project demonstrated this constant dialogue with a design that consciously involves our senses: from the reconstruction of Palazzo di Lorenzo (1984) to the redevelopment of the spaces of the "Secret Gardens" in Gibellina. The earthquake as a sort of reward, it offered to numerous architects, including Venezia, Quaroni and Burri, an opportunity to improve their abilities.

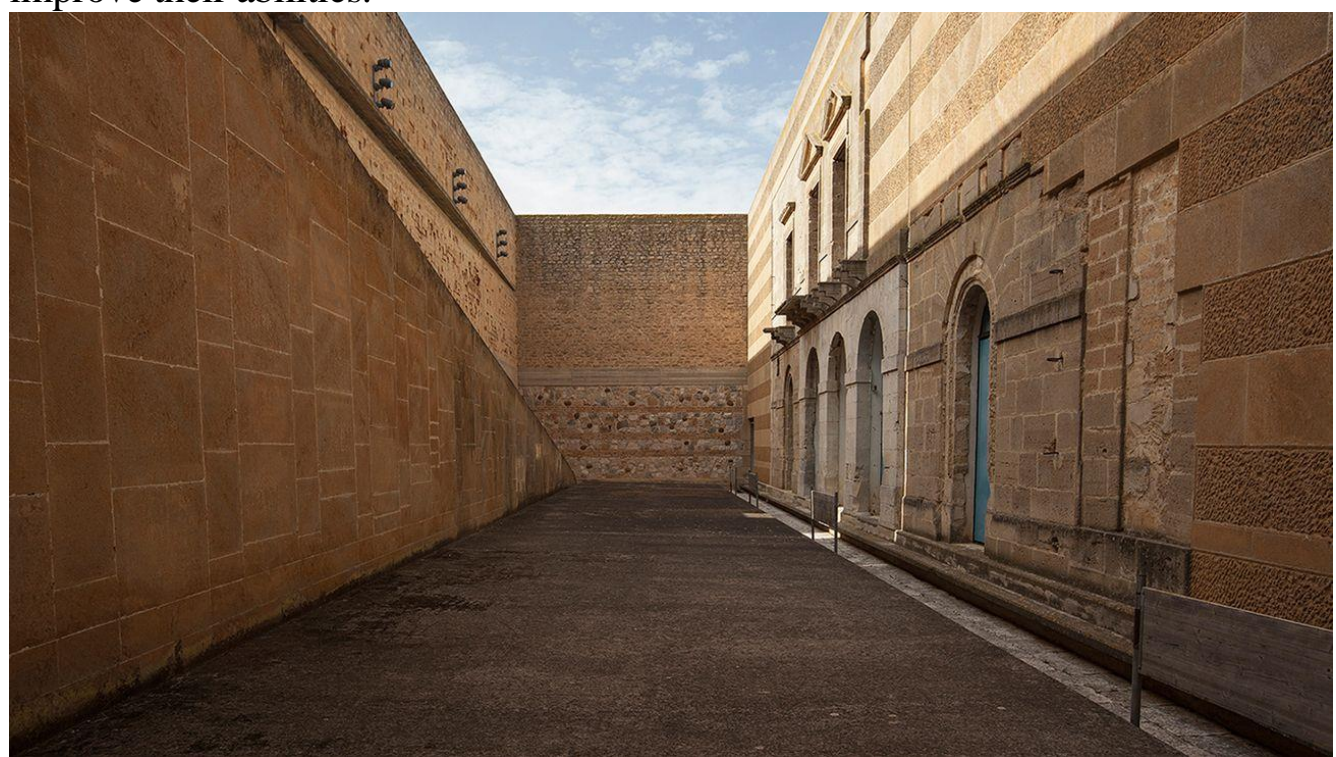

Figure 4. Di Lorenzo Palace, Gibellina, Italy

Source: http://www.artribune.com/progettazione/architettura/2018/01/francesco-venezia/.

Gibellina's works show how much the relationship that architecture has with reality is quite never passive, and rarely puts itself in relation to the place. Venezia himself says: "It is often the result of deep conflicts, wounds, lacerations. I become suspicious when reality appears as a careful listening and interpretation of a site. Architecture goes in hard and the site does not desire to be occupied by architecture - the sites are as good as they are." ${ }^{13}$ And how does a site feel when it lives the wound of an earthquake that suddenly interrupted the relationship of an

12. Ibid, no. 4,13 .

13. Ibid, no. 8, 28. 
entire community with a territory? How could we intervene after a physical, architectural, social moment of mourning? Would the site choose everything to stay suspended in time, like ruins do for example?

From that moment on, it begins the construction of a concrete relationship between architecture and the place. This imposition is violently refused by the site at first. But architecture, when it is architecture and not a hedonistic soliloquy of an egocentric personality, when everything is finished, gives the possibility to offer an image of that place, unimaginable without the presence of that intervention, "assuming intervention could express this capacity to interpret this action of contrast. Reconciliation, that is revealed to things done, is never preliminary, it is a result. It is a result that tells us that our action has been successful." ${ }^{14}$

In the case of Gibellina projects, the architecture of Venezia returns to have a sediment, a link with the ground that most of the contemporary architecture does not seem to have. In many of today's architectures the gesture of founding is put aside starting from the first steps of conception: it is not based on a conceptual sediment, it seems not to struggle anymore, it gives up by renouncing to live dramatically the drama to unload its importance.

His architecture represents a critique to a contemporary production that is increasingly concerned with proposing novelty, through a collection of objects that are much more similar to design objects, rather than objects of architecture: "Objects similar to corks floating on water and not taking any action against things. They do not oppose anything, they simply exist, they run before our eyes like in a big fashion show and in the course of a few years they will leave the catwalk. (...) There are architects who dream of buildings similar to clouds, so they can float up in the air without dumping their thousands of tons on the ground with all the consequences that this action entails. We are witnessing the flowering of objects that, not by chance, lend themselves to being an advertising scene. (...) thus fulfilling the fatal conjunction of two fleeting realities. ${ }^{15}$

In Lorenzo's palace project, space seems to dominate the form. It does not give occasions to the image to be charming, but it is organized to restore a significant and temporal "collocation" to the objects that overcame to the traumatic event (see Figure 2). The "dispositio" is not always the same as the original space but continues to allow the integration between the designed material and the environment. And not only matter and materials belong to that environment, but also echoes of distant cultural influences. We perceive them in the secret areas of the Gardens of Gibellina, without recognizing the existing Arab, Norman and Sicilian structures. In a project of a house (not yet realized) in Palazzolo Acreide, it is introduced a theme on which Venezia will reflect on several occasions: the coexistence of two worlds, of the double. Moreover, his relationship with Naples, by origin and training, obliges him immediately to dialogue with an inferior reality (the thousand cavities in the subsoil of Naples) and a superior reality (the city in the sunlight). In the design of this small house, the section shows a small cave, and shows a character of domesticity suggested by the reduced size of everything. But

14. Ibid.

15. Ivi, 28-29. 
the coexistence of these two realities, as he describes speaking of the project, is well highlighted through a vertical axis that connects and both physically and symbolically unites the inferior world, the underground (the cave) and a superior world, the loggia. An axis also transformed into a possibility to ventilate the house, is a ventilation shaft, and an interior garden. ${ }^{16}$

\section{The Memory Project}

Among the merits of the Italian culture of the twentieth century there is that of having given birth to some of the most interesting and bright opportunities for the design of exhibitions and installations. In Pompeii two exhibitions were set up but we will deal with the one set up in the amphitheatre. The exhibition at Palazzo Grassi about the Etruscans (2000), and the exhibition about Jean Arp in Rome (2017) in the church of Santa Maria degli Angeli make Francesco Venezia a worthy heir of this process.

The two exhibitions, Pompeii and Europe, 1748-1943 in the National Archaeological Museum of Naples, and the other in the amphitheater of the excavations of Pompeii, were inaugurated in May 2015. ${ }^{17}$

The genesis of the project for the amphitheatre of the excavations of Pompeii can be recognized through an image that is part of a series of preparatory sketches for the exhibition. The same typology of sketch can be recognized in the phase of conception of the exhibition for the National Archaeological Museum: this is the co-factor that suggests the actual conceptual relationship between the two set-up occasions. In one of these sketches it is easy to recognize a design of a beam diagonally slanting a dome to which a transverse cut has been made. The path of the ray comes to some figures, lying on the floor, whose features are not recognized. The effect of light reminds us, as Dal Co says in his book, ${ }^{18}$ the atmosphere of an interior of the ancient era: the temple of Mercury in Baia, in the Campi Flegrei, a volcanic area close to Naples. It is a temple of the I. Sec. D.C, always been a destination for travelers interested in ancient ruins.

This image, which turns into an ideogram, represents the conceptual foundation of the entire exhibition of Pompeii. The site that has been chosen for the construction is the Roman amphitheater that was built to give gladiators a place where they could improve their fighting skills. There are testimonies of these activities in several graffiti found in the walls of the archaeological excavations. The elliptical arena is about six meters far from the second order of the cavea. Venezia arranges a pyramid by using the ruins of this place. He uses wood both

16. F. Venezia, La Natura Poetica dell'Architettura (Pordenone: Giavedoni, 2010), 67.

17. As concerns these two expositions, it is useful to consult the catalogues: M. Osanna, M. T. Caracciolo, L. Gallo, (ed.) Pompei e L'Europa, 1748 - 1943 (Milano: Electa, 2015); Aa.vv. Pompei. La Fotografia (Milano: Electa, 2015). The two expositions were examined and described in: F. Dal Co, Francesco Venezia e Pompei. L'Architettura come l'Arte del Porgere (Palermo: Lettera Ventidue, 2015), and the text above refers to this part.

18. Dal Co, Francesco Venezia e Pompei. L'Architettura come l'Arte del Porgere, 2015, 33. 
for the structural part and the cladding, but trying to give the idea of a stone texture. Dal Co, in his text, establishes a relationship between the form of the temporary building chosen by Venezia and the architectural form considered by Ètienne Boullée in his "Architecture. Essai sur l'art" the most appropriate for the "temples of death. It is defined as: "a buried architecture, with squat and slashed proportions." 19

This is how the pyramid appeared inside the amphitheater, like an object that had found a sediment below ground level. And the choice of a pyramid shape inevitably puts him in dialogue with some famous projects by Boullée. This dialogue does not place Venezia in a position of submission, on the contrary, it contrasts it in a clever way to the suggestions that Boullée makes about the funerary architecture. Since Venezia decides to build a real cenotaph inside the amphitheatre it possesses all the features of a funerary architecture. It is Dal Co that in the text suggests the relationship with the "famous funerary monument in honor of viscount Turenne, the Marshal of France which served Louis XIV, and fell in the battle of Salzbach in 1675, conceived by Boullée more than a hundred years later, much probably in 1782." ${ }^{20}$ For this project Boullee chooses the pyramidal shape, cut at the tip, placing it in the center of a rectangular enclosure, and isolated on each side. The absence of any decoration, the pyramidal trunk shape and the central insulating in an encloded area are other choices made by Venezia. The difference lies in the eccentric collocation of his pyramid that occupies one of the two centers of the ellipse of the amphitheater.

The animated dialogue that Venezia ideally establishes with Boullée also passes through the choice to dedicate the architectural "object", not to a valiant leader but rather to bodies without a name, the "molds of Pompei". These are the result of a process of revitalization of hollow shapes that are the result of the decomposition of dead bodies following the eruption of Vesuvius. The lava flow of that special mixture of materials has returned not the perfection that a human body has, but the sketches of bodies expressing the last moments of the common lives, through the gestures that have been immortalized by death. As a result, the protagonists of this exhibition are lifeless plastic forms.

This choice immediately distances the pyramid of Venezia from the idea of a cenotaph which by definition comes from the union of the words Kenós, empty, and Taphós, tomb but above all defines a tomb that does not contain the body of the deceased person to whom it is dedicated. It is therefore not a VACUUM OF SPACE, but a "inhabited monument" and this turns it into ARCHITECTURE.

The features of their last dramatic movements transform these lifeless casts into a timeless testimony, as if we could still hear their last cry or their last breath. This extension of figures in their last contorted movement is arranged in such a way that those who visit the exhibition can have a view from above, thanks to the presence of a raised and circular path.

At the entrance, at the top of the pyramid we find a gnomic hole, like the one in the sketch that was part of the first step in the design process of the two exhibitions. This hole allowed the light to enter the space and to touch and

19. Ibid, 34 .

20. Ivi, 35 . 
illuminate the casts. But the effect of light changes with the changing of the hours and the position of the sun: as well as actors from time to time illuminated by the limelight, the bodies reclaimed for a few hours their role of protagonists. This is because the dome is not cut at one of the circumferences of the hemisphere that are parallel to the ground, but along a circumference drawn by an inclined plane, in order to form a circle of light instead of an ellipse (see Figure 5).

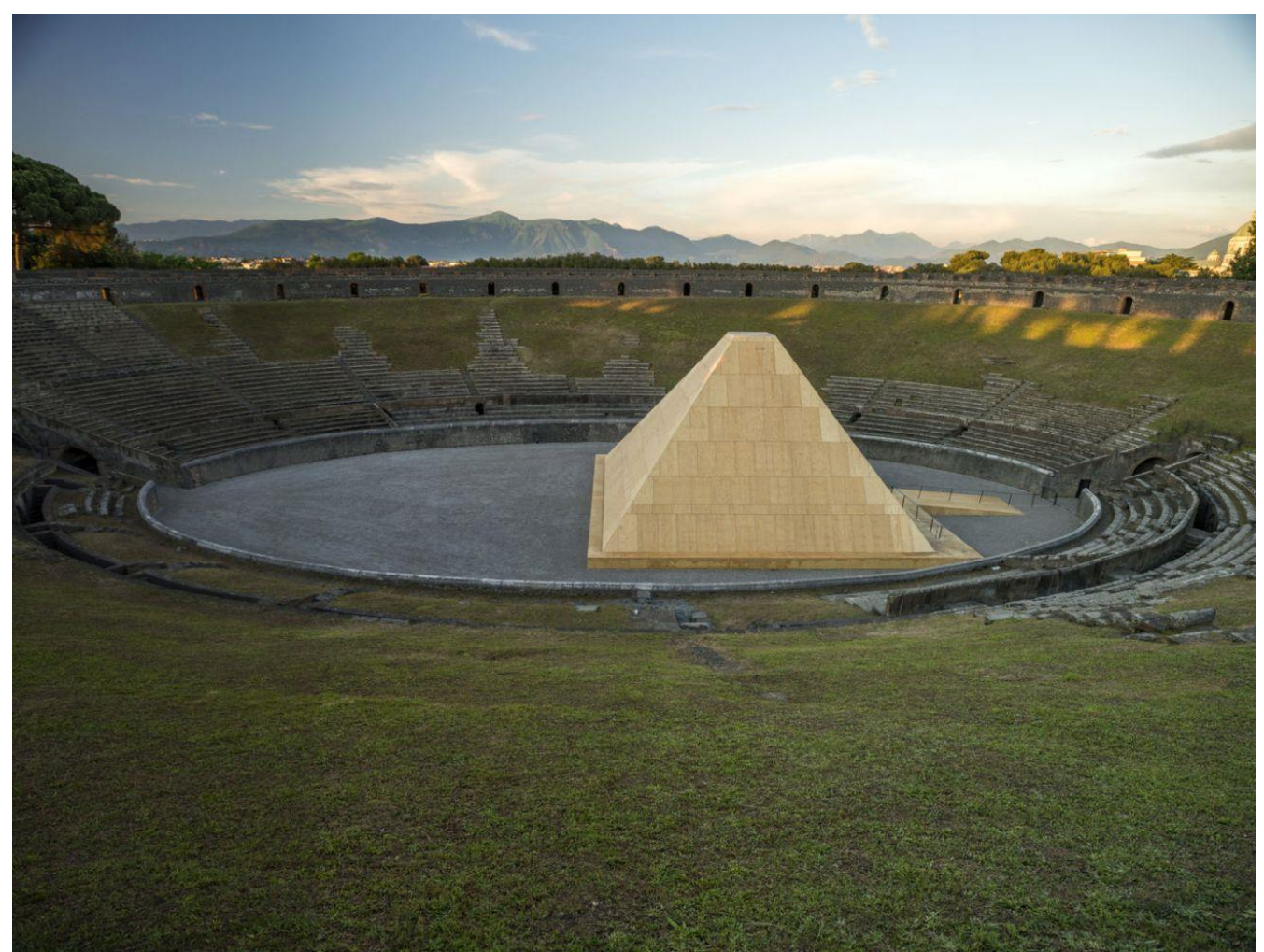

Figure 5. Roman Amphitheater in Pompeii with the Venezia's Pyramid

Source: http://www.artribune.com/progettazione/architettura/2018/01/francesco-venezia/.

The visit of this temporary architecture shows us that between Venezia and Boullee there is a sharing of references and models and a similarity of suggestions. The model of the temple of Mercury in Baia, must surely be part of the memory of education of the Neapolitan architect Venezia. Some coincidences, as Dal Co points out, cannot be a coincidence: for example, the diameter of the circular thermal room is the same as the pyramid, and this gives rise to the overlap between a circle and a square. This overlap is the same one that Boullee adopts in the Tourenne cenotaph project ${ }^{21}$. Even the diagonality of the ray of light in the pyramid is definitely inspired by the light that enters the thermal room from one of the side windows.

It should be recalled that Boullee was an expert of the temple of Mercury, thanks to the reliefs that Abraham - Louis Ducros had conducted during his first trip to Naples in 1778, four years before the Cenotaph's project.

21. Ivi, 39. 
Moreover, the changeable shadow play that the casts cause, thanks to a slight super elevation that Venezia choose for them, ensures that in the design references it is perceptible Piranesi and his architectures of shadows.

On the sides, along the curved walls, there are the photographs taken since the mid-nineteenth century during the excavation works.

"Modeled without art or imitation" as Luigi Settembrini observed in the nineteenth century, the casts restored body and figure "to the pain of death". Figures of the immutable, were greeted by Venezia within an ephemeral construction, therefore inevitably paradoxical. For a very short time, however, the installation ensured a roof - a body as Boullée would say." 22

The cenotaphs have the function of "perpetuating the memory of those to whom they were consecrated" and this is the reason why they must be designed in order to resist the offenses of time, as stated in the Essai of Boullée. "But the cenotaphs, as we have seen, are empty monuments: only fame lives inside them. For the bodies, on the other hand,they are reserved modest coverings, similar to those that Venezia designed for casts" ${ }^{23}$ (see Figure 6).

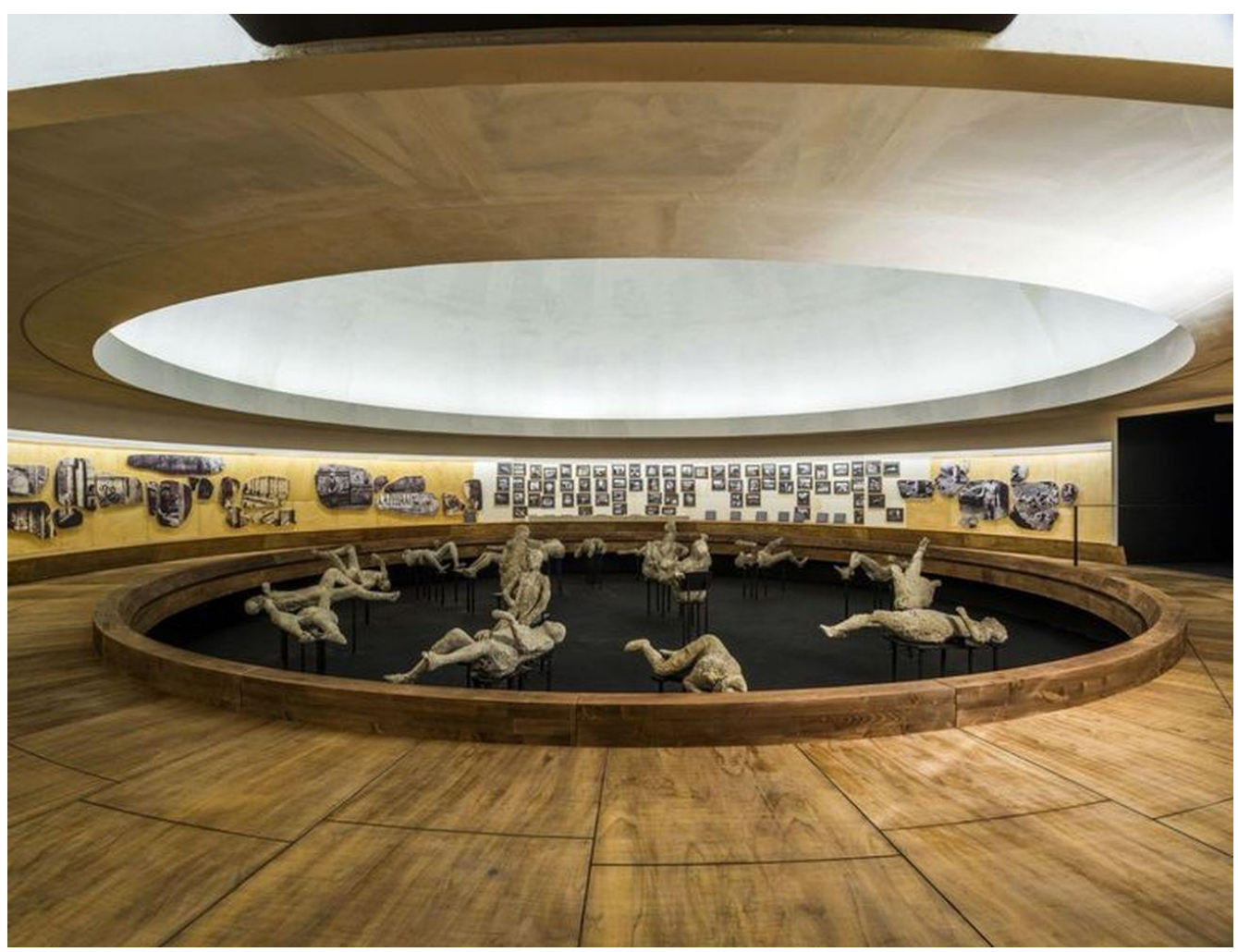

Figure 6. Interior of Pyramid with Casts

Source: http://www.artribune.com/progettazione/architettura/2018/01/francesco-venezia/.

Fifty years after the death of the artist Jean Arp (1887 - 1966), the Special Superintendency for the Colosseum and the central area of Rome and the National Roman Museum decided to honor him by asking for an exhibition project to the

22. Ivi, 41-42.

23. Ibid. 
Neapolitan architect Francesco Venezia and evocative space that was chosen were the great Halls of the Thermal Baths of Diocletian. Another opportunity for the architect to compete with the great architectural history, and to challenge the obvious and winking project. The works, which follow a rigorous division into the spaces chosen for the exhibition, underline a relationship with classicism and with the poetry of the fragment, themes, as we could understand in the text, dear to the design and theoretical mentality of Venezia.

"The exhibition appears as isolated and almost suspended in the immense space of the two Halls of the Baths" explains Venezia "metaphor of the difficult individuation, in the work of Jean Arp, of a reflection of the ancient or of a character of the eminently historical soul". "The pendulous stems that support the bodies, illuminating, the walls of the exhibitors, the bases of the sculptures intertwine in perspective and with calculated variety five colors: black, green, red, yellow and blue. They are recurring colors in the artist's graphic work."

The conceptual organization of the exhibition is imposed in Venezia, which has to resolve some important conditions in the conception of the space dedicated to the artist. The choice focuses in particular on the sculptural activity of the 30s that obliges the architect to favor a fruition of the works organized through a multiplicity of directions of the gaze. It is mentioned only his participation in the Dadaist movement, his use of collages and the language influences coming from his friendship with Matisse. The second limitation has a spatial nature and comes from having chosen as a space for the exhibition, a unique hall for the baths.

All the works had to find a deserving placement within a spatial limit that must have influenced the ideation of Venezia. Almost all the works have been arranged outdoors. "And here and there the parentheses of unexpected glimpses that frame the mosaics, the statues, the ancient marbles, the sample of columns and architectural friezes of the Roman museum as mirages of a remote and incumbent horizon of confrontation with a past in which the same Arp he immersed himself, drawing inspiration from it." 25

\section{Conclusion: Architecture as Reward}

The distance that Venezia assumes with regard to perfection, which does not mean methodological or programmatic superficiality, but respect for human daily life, outdistances its work from the danger that threatens contemporary architecture: considering every architectural occasion as a self-portrait, as an object constantly longing for that fixedness given by fame, and by the aspiration of eternity. The infinite and multiple stresses to which the surface architecture is subjected, shift the attention in different directions, putting it away from the depth where the movement is slow. It reacts and manifests itself as a force that sometimes is evident. ${ }^{26}$

24. http://www.artribune.com/tribnews/2016/09/jean-arp-terme-diocleziano-roma-dada/. 25. http://www.succedeoggi.it/2016/10/arp-lequilibrista/.

26. Op. Cit., no. 11, 33. 
This is the layer to which Venezia seems to be interested, a divine exactness that manifests itself through its voluntary superficial absence, but which is present there, where nobody sees it.

The humanity of architecture, daily life and the non-aspiration to eternity leads back to the silence of the forms and the wisdom of building. Moreover, it places the architect's work on a respectful path already traced, where before being transported by temporal syntax, it would be better to abdicate from the hedonistic will of power.

The works of Francesco Venezia - fortunately - do not allow themselves to be considered as concluded. His relationship with the unfinished gives his poetics the idea of "becoming". Each of his generous transmission of experience allows us to take one more step towards a process of self- discovery of the sense of doing architecture. It is the practice of the good teacher, who indicates by directing a path which only those who walk through it can find out where it will lead them.

\section{Bibliography}

Aa.vv. Pompei. La Fotografia. [Pompeii. The Photography.] Milano: Electa, 2015.

Aubenque, P. Le Prudence chez Aristote. [Prudence at Aristotle.] Paris: Presses Universitaires de France, 1963.

Colonna, A. Genealogia del Presente e Storiografia dell'Architettura. Appunti dalla Didattica e per la Ricerca. [Genealogy of the Present and Historiography of Architecture.] Notes from Teaching and Research. Potenza: Calebasse ricerche, 2015.

Dal Co, F. Francesco Venezia e Pompei. L'Architettura come l'Arte del Porgere. [Francesco Venezia and Pompeii. Architecture as the Art of Offering.] Palermo: Lettera Ventidue, 2015.

Espuelas, F. Madre Materia. [Mother Materia.] Milano: Marinotti, 2012.

Osanna, M., M. T. Caracciolo, L. Gallo. (ed.) Pompei e L'Europa, 1748 - 1943. [Pompeii and the Europe, 1748 - 1943.] Milano: Electa, 2015.

Venezia, F. Rovine e non Finito. [Ruins and Unfinished.] Venezia, 2007.

Venezia, F. La Natura Poetica dell'Architettura. [The Poetic Nature of Architecture.] Pordenone: Giavedoni, 2010.

Venezia, F. Che Cosa è l'Architettura. Lezioni, Conferenze, un Intervento. [What is Architecture. Lectures, Conferences, an Intervention.] Milano: Electa, 2013. 